\title{
Hepatic stellate cells: central modulators of hepatic carcinogenesis
}

\author{
Alexandra I Thompson, Kylie P Conroy and Neil C Henderson*
}

\begin{abstract}
Hepatocellular carcinoma (HCC) represents the second most common cause of cancer-related death worldwide, and is increasing in incidence. Currently, our therapeutic repertoire for the treatment of HCC is severely limited, and therefore effective new therapies are urgently required. Recently, there has been increasing interest focusing on the cellular and molecular interactions between cancer cells and their microenvironment. HCC represents a unique opportunity to study the relationship between a diseased stroma and promotion of carcinogenesis, as $90 \%$ of HCCs arise in a cirrhotic liver. Hepatic stellate cells (HSC) are the major source of extracellular proteins during fibrogenesis, and may directly, or via secreted products, contribute to tumour initiation and progression. In this review we explore the complex cellular and molecular interplay between HSC biology and hepatocarcinogenesis. We focus on the molecular mechanisms by which HSC modulate HCC growth, immune cell evasion and angiogenesis. This is followed by a discussion of recent progress in the field in understanding the mechanistic crosstalk between HSC and HCC, and the pathways that are potentially amenable to therapeutic intervention. Furthermore, we summarise the exciting recent developments in strategies to target HSC specifically, and novel techniques to deliver pharmaceutical agents directly to HSC, potentially allowing tailored, cell-specific therapy for HCC.
\end{abstract}

\section{Introduction}

Hepatocellular carcinoma $(\mathrm{HCC})$ represents the second most common cause of death from cancer worldwide, and was responsible for nearly 746000 deaths in 2012 [1-3]. In patients with cirrhosis, HCC is the most common cause of death. Worldwide, chronic hepatitis B virus infection remains the major risk factor, with $80 \%$ of cases occurring in eastern Asia and sub-Saharan Africa. In most countries, the mortality rate of $\mathrm{HCC}$ approximates the incidence, which is increasing [4-6]. This is partly due to the rising prevalence of advanced fatty liver disease and chronic hepatitis $\mathrm{C}$, alongside other risk factors such as hepatitis B infection and alcohol-related cirrhosis. Some progress has been made with prevention, for example emerging antiviral agents and vaccination for hepatitis B. However, the vast majority of $\mathrm{HCC}$ cases are associated with fibrosis, and $90 \%$ of tumours develop in cirrhotic livers [4, 5, 7-10]. Furthermore, liver disease severity markers correlate with tumour formation $[4-6,9,11-14]$. Currently there are

\footnotetext{
* Correspondence: Neil.Henderson@ed.ac.uk

MRC Centre for Inflammation Research, The Queen's Medical Research

Institute, University of Edinburgh, 47 Little France Crescent, Edinburgh, UK
}

no effective anti-fibrotic therapies available to halt the fibrosis-cirrhosis-HCC continuum. Patients who present with early disease may benefit from resection, transplantation or loco-regional therapy, however many are unsuitable for curative treatment due to advanced malignancy, or the severity of co-existing liver disease. The multi-tyrosine kinase inhibitor sorafenib is the only available systemic chemotherapy agent with survival benefit for advanced stage HCC, however its use is limited to those with well-preserved liver function [11]. Whilst there is scope to optimize our use of existing treatments, for example by targeting tumours earlier and combining local and systemic approaches, efforts to broaden our chemotherapy armamentarium have been disappointing. Numerous molecular therapies with robust preclinical evidence for efficacy have failed to show benefit in clinical trials. This may in part reflect the abnormal tumour microenvironment, which acts to support the persistence and growth of cancer cells, and has resulted in the peri-tumoural stroma and its cellular inhabitants becoming an intense area of study in the search for efficacious therapies for HCC.

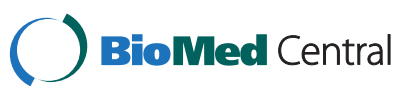

(c) 2015 Thompson et al. This is an Open Access article distributed under the terms of the Creative Commons Attribution License (http://creativecommons.org/licenses/by/4.0), which permits unrestricted use, distribution, and reproduction in any medium, provided the original work is properly credited. The Creative Commons Public Domain Dedication waiver (http:// creativecommons.org/publicdomain/zero/1.0/) applies to the data made available in this article, unless otherwise stated. 
In this review we focus on the complex interplay between hepatic stellate cell (HSC) biology and hepatocarcinogenesis. The mechanisms by which HSC may facilitate $\mathrm{HCC}$ development and progression are likely to involve diverse biological processes including regulation of extracellular matrix (ECM) turnover, growth factor and cytokine signalling, promotion of tumour angiogenesis and immunomodulation. We will discuss how this burgeoning area of research may yield exciting new therapies for patients with HCC.

\section{Role of the stroma in hepatocarcinogenesis}

The stroma is a central component of both hepatic fibrosis and carcinogenesis, and is a key player in the cellular and molecular mechanisms linking these processes. It is still unclear, however, whether liver fibrosis specifically promotes HCC, or if it is merely a woundhealing by-product of chronic hepatic injury and inflammation, with no direct impact on liver cancer formation $[8,13-15]$. Evidence would suggest the former; the identification of gene signatures from non-tumoural tissue correlating with late recurrence of HCC, supports the concept of a 'field effect' in cancer development [9, 11, $13,14,16-25]$.

Following liver injury, quiescent HSC become activated to matrix-secreting myofibroblasts and are the major source of ECM proteins during liver fibrogenesis $[8,13,26]$. As master regulators of the fibrotic matrix, HSC may therefore directly influence HCC formation via effects on the tumour stroma. Furthermore, it is well established in other systems that complex intercellular signalling networks exist between tumours and cancerassociated fibroblasts, contributing to cancer initiation, growth and progression $[8,13,16-19,21-26]$. Tumour secretion of cytokines such as transforming growth factor- $\beta$ (TGF- $\beta$ ), stimulate myofibroblast activation leading to profound changes in ECM composition and organization. Therefore, HSC or HSC-secreted products may be either permissive or necessary for oncogenesis and HCC persistence. In other cancers, the identification of pathways that the tumour depends upon for growth and proliferation, so-called "oncogenic addiction loops" has led to revolutionary therapeutic approaches. The landmark discovery of the protein kinase oncogene BCR-ABL and subsequent development of imatinib, allowed curative treatment of chronic myeloid leukaemia, and has paved the way for targeted therapies in other malignancies [27, 28]. Despite extensive genomic profiling of HCC, targeting other non-kinase oncogenes such as RAS and MYC has proven more challenging. The identification of promising candidate pathways targeting inhibition of a driving molecular alteration, which is also applicable in a significant proportion of patients, remains an elusive yet alluring goal [29]. Furthermore, the microenvironment may modulate susceptibility to inhibition of specific oncogenic pathways. Straussman et al. developed a co-culture system to test the ability of 23 stromal cell types to influence the susceptibility of 45 different cancer cell lines to 35 therapeutic agents [7]. They demonstrated that stroma-mediated resistance to anti-cancer drugs (especially targeted agents) is common. In particular, although melanomas expressing mutant BRAF respond to vemurafenib, hepatocyte growth factor (HGF) secretion by peri-tumoural stromal cells correlated with resistance to vemurafenib-induced cell death $[7,30,31]$. This illustrates the importance of stroma-derived resistance to chemotherapy, in many different organs and disease settings. Therefore, in the search for key driver mutations in HCC, the effect of the microenvironment cannot be underestimated. This may necessitate combinations of chemotherapeutic agents, to neutralize specific stromal interactions, resulting in greater overall clinical efficacy.

\section{$\mathrm{HSC}$ in $\mathrm{HCC}$}

It is well-known that activated HSC infiltrate HCC stroma and peri-tumoural tissue, and are localised around tumour sinusoids, fibrous septae and the tumour capsule [32-34]. Activated HSC have also been identified around the periphery of dysplastic nodules within the liver [35]. Following activation to the myofibroblast phenotype, HSC secrete substantial amounts of ECM proteins into the stroma. Fibrotic matrix deposition and degradation by HSC is tightly regulated in the liver. For example, tissue inhibitors of metalloproteinases 1 (TIMP-1) secretion favours scar deposition by inhibiting the endogenous matrix-degrading activities of various matrix metalloproteinases (MMPs). However, the balance of TIMPs and MMPs is complex; activated HSC are also a major source of MMP-2 in vitro, elevation of which has been correlated with increased tumoural collagen I, extracellular remodeling, and HCC progression [12, 36, 37]. Interestingly, the biomechanics of the ECM are also relevant. Differentiation of primary hepatocytes is inhibited by culture on a stiff collagen gel, with accompanying promotion of proliferation $[38,39]$. In vitro increasing matrix stiffness has also been shown to directly stimulate growth of the HCC cell lines, HuH-7 and HepG2, and reduce chemotherapyinduced apoptosis [40]. Integrin $\beta 1$ signalling was an integral driver of this response, via Fak, Erk, Pkb/Akt and Stat3 pathways [40]. Furthermore, stromal stiffness is selfperpetuating, causing stellate cell activation, and therefore further fibrosis $[15,41,42]$. Data in humans support these experimental findings. Ultrasound elastography has demonstrated that measurements of liver stiffness predict HCC development [43-46]. Similarly, established HCC demonstrates further increases in matrix stiffness, more so than the peri-tumoural hepatic parenchyma [47]. The 
mechanical tension provided by an altered ECM is likely to act on HCC development and progression via outsidein signalling, for example by integrins, (discussed below) to support tumour growth and progression. This has also been observed in other malignancies, such as a mouse model of breast cancer [48]. Hepatocarcinogenesis in the context of cirrhosis, however, is a unique model of diseased ECM, and an ideal setting to further characterise and potentially target stromal drivers.

\section{Integrins as mediators of HSC/HCC crosstalk}

Consisting of an $\alpha$ - and $\beta$-subunit, integrins form a family of transmembrane receptors that 'integrate' the extracellular and intracellular environments through binding ECM and the cytoskeleton [49]. Via transduction of signals between the internal and external cellular domains, integrins regulate cell adhesion, spreading, migration, proliferation and differentiation as well as ECM deposition and remodelling [50].

In activated HSC downstream integrin signalling, via the focal adhesion kinase (FAK)-phosphatidylinositol 3-kinase (PI3K)-Akt signaling pathway, promotes ECM deposition [51]. Increased ECM stiffness in vitro enhances integrin expression and activity and focal adhesion formation, [48] with subsequent activation of downstream integrin signalling within the hepatocyte that may nurture the growth and survival of precancerous cells. Matrix stiffness has been reported to dictate differentiation and chemotherapeutic resistance of human HCC cell lines, with softer matrices abrogating hepatoma proliferation and stiffer platforms promoting proliferation [40, 52]. In an elegant in vivo study, cells from the HCC cell line McA-RH7777 were implanted into rats treated with carbon tetrachloride $\left(\mathrm{CCl}_{4}\right)$ for varying lengths of time, thereby modelling tumourigenesis on different liver stiffness backgrounds. Microarray analysis of the tumours demonstrated a positive correlation between matrix rigidity and tumour angiogenesis [52]. Correlations between collagen expression, integrin expression and tumourigenicity have also been reported in human HCC and murine HCC models $[53,54]$. Characterisation of integrin expression in hepatoma cell lines has revealed a high degree of heterogeneity in integrin expression [55]. Comparing two clinically relevant mouse models of $\mathrm{HCC}$, plateletderived growth factor (PDGF)-C overexpressing and PTEN null mice, Lai et al. demonstrated that each model had a specific pattern of integrin gene expression, further indicating HCC heterogeneity [54].

The $\beta 1$ integrin subfamily has been extensively studied in the context of HCC, and hepatocarcinogenesis is associated with the enhanced expression of integrins $\alpha 1 \beta 1, \alpha 2 \beta 1$ and $\alpha 3 \beta 1$ and the acquisition of a migratory phenotype by hepatocytes [56-58]. Further, assessment of integrin $\beta 1$ expression in human HCC tissues demonstrated a positive correlation with ECM stiffness, pathological grade and metastasis [59]. Blockade of integrin $\beta 1$ in vitro significantly abrogates migration and invasion of HCC cell lines induced by TGF- $\beta 1$ and epidermal growth factor (EGF) $[58,60]$. Conversely, overexpression of integrin $\beta 1$ has been reported to enhance HepG2 cell migration [61]. More recently it has been reported that integrin $\beta 1$ is involved in the transduction of ECM signalling into HCC cells, resulting in the downstream activation of angiogenic signalling [52]. Utilising a high-stiffness gel to culture HCC cell lines Dong et al. found that vascular endothelial growth factor (VEGF) expression is suppressed by treatment with an integrin $\beta 1$-specific antibody [52]. SERPINA5 (Protein $C$ inhibitor), a member of the serine protease inhibitor superfamily know to have anti-metastatic and anti-angiogenic effects, [62] is down-regulated in human HCC tissues and further assessment of it's anti-tumourigenic activity demonstrated that this was mediated by effects on the fibronectin-integrin $\beta 1$ signalling pathway [63]. The relationship between integrin $\beta 1$ and ECM stiffness in $\mathrm{HCC}$ is further highlighted in a study where resistance of the HCC cell line, Hep3B, to sorafenib was found to be mediated by integrin $\beta 1$ and its downstream effector JNK [64].

Other integrin subunits, in addition to $\beta 1$, have been reported to have key roles in HCC progression. Fan et al. have reported integrin $\alpha 6$ expression to strongly correlate with HCC metastasis in humans [65]. Integrin $\alpha 6$ overexpression in HCC cell lines (utilising a viral short hairpin RNA-mediated strategy) revealed that integrin a6 can form a complex with CD151, a tetraspanin protein also associated with HCC invasion [65]. Further investigation in vivo indicates that the CD151/ 66 complex stimulates the PI3K-Akt signalling pathway leading to enhanced epithelial-mesenchymal-transition (EMT) of HCC cell lines [65].

Crosstalk between integrins and TGF- $\beta$ signalling has also been studied in hepatocarcinogenesis. TGF- $\beta$ receptor I (TGF- $\beta$ RI) activation has been reported to promote HCC cell invasiveness through phosphorylation of the intracellular portion of the $\beta 1$ subunit of the $\alpha 5 \beta 1$ integrin via Smad-2 and Smad-3, leading to an insideout conformational change and stimulating vascular invasion [66]. Up-regulation of other integrins including $\alpha 3 \beta 1$ and $\alpha 6 \beta 1$ by TGF- $\beta 1$ has also been reported, leading to increased tumour invasiveness into surrounding tissues [67]. Furthermore specific crosstalk between fibronectinbinding integrins and TGF- $\beta 1$ can promote cell cycle progression in HCC cells through activation of c-Src [68]. Crosstalk between integrins, growth factor receptors and ECM proteins including collagen, have further been shown to alter downstream signal transduction pathways such as Smad, promoting both hepatocyte proliferation 
and sustaining HSC activation $[69,70]$. TGF- $\beta 1$ has also been reported to modulate $\alpha 5 \beta 1$ expression and synergistically enhance integrin-mediated FAK phosphorylation and cell adhesion in the HCC cell line SMMC-7721 [71]. Therefore, integrins (via modulation of TGF- $\beta$ signalling) may render hepatocytes less sensitive to pro-apoptotic signals in early HCC stages, and more sensitive to tumourigenic differentiation and metastasis formation in advanced HCC.

\section{HSC growth factor signalling}

HSC have been shown to favour HCC tumourigenicity, potentially as a result of a change in their secretory phenotype upon activation. In vitro studies, using conditioned media from activated HSC, have consistently reported increased proliferation, migration and invasion of tumour cells [72-74]. Isolation and subsequent coculture of human intratumoural HSC with hepatoma cell lines enhanced their viability and migratory capacity [72]. Furthermore, co-transplantation with HCC cells into nude mice promoted tumour formation and growth [75]. Utilising both co-culture and conditioned media from primary human HSC Giannelli and colleagues determined Laminin-5 to be a mediator of HSC-induced HCC migration via its activation of the MEK/ERK pathway [76]. This is supported by in vivo experiments, in which co-transplantation of murine activated HSC with murine HCC cells (H22 line) into immunocompetent mice resulted in significantly larger tumour volumes [73]. Furthermore, implantation of human HCC cell lines (PLC and Hep3B) into nude mice did not form tumours unless activated HSC were concurrently implanted [72]. HepG2 cells did form tumours when implanted alone, however tumour growth was more rapid when co-transplanted with activated HSC [72]. Activated HSC secrete a broad range of growth factors including HGF, TGF- $\beta$, fibroblast growth factor (FGF), EGF, VEGF and insulin-like growth factor (IGF). The following sections discuss how these growth factors are involved in HCC pathogenesis.

\section{Hepatocyte Growth Factor}

HGF is expressed by HSC and myofibroblasts, [77, 78] and is a highly potent hepatocyte growth factor regulating cell proliferation, migration, survival and angiogenesis [79-82]. As such it is widely regarded as a key factor for tumour cell invasion and metastasis [83]. HGF binding to its receptor, c-MET, induces receptor homodimerization and a subsequent phosphorylation cascade. A transmembrane receptor tyrosine kinase, c-MET is found in 20-48 \% of HCCs, [84-86] and has been shown to be expressed by multiple HCC cell lines [72]. Correlations between increased c-MET and HCC tumour size or invasiveness of HCC have been reported in some studies [87, 88]. c-MET overexpression is also associated with a reduced five-year HCC survival, and a c-MET-regulated expression signature has been reported to define a subset of patients with poor prognosis and an aggressive phenotype [89, 90]. Within HCC tumours, activated HSC have been found to initiate signalling pathways downstream of c-MET, including NF- $\mathrm{kB}$ and ERK leading to tumour proliferation and migration $[72,91]$.

The pro-tumourigenic activity of fibroblast-secreted HGF has also been reported in vitro. Conditioned media from isolated and activated HSC, pre-incubated with anti-HGF antibodies, was found to abrogate the proliferative and migration-inducing effects on HCC cell lines, seen in non-treated conditioned media [72]. This has also been demonstrated in cancer-associated fibroblasts (CAF) isolated from HCC, where treatment of CAF-conditioned media with an anti-HGF antibody significantly reduced HCC proliferation in Hep3B and MHCC97L cell lines [74]. Moreover, a HGF/c-MET specific antagonist, NK4, has been found to inhibit markedly the fibroblast-induced invasion of cancer cells, both in vitro and in vivo, [92-94] although this has yet to be translated into the clinical setting. A murine model of $\mathrm{HCC}$ with similarities to the human disease was recently developed, in which progressive fibrosis and cirrhosis, initiated by ectopic expression of PDGF-C, precedes hepatocyte dysplasia and eventual HCC development [95]. Analysis of these PDGF-C transgenic mice demonstrated that expression of hepatic HGF and its receptor were elevated at the time point at which dysplastic foci are present, further suggesting a protumourigenic role for HGF. Activation of HGF/c-MET signalling has also been shown to enhance HCC chemoresistance. Conditioned media from the activated HSC cell line LX-2 enhanced resistance of the HCC cell line Hep3B to the chemotherapeutic agent cisplatin, an effect mediated by HGF [96]. Tumour cells may also potentiate prometastatic c-MET signalling via an autocrine mechanism involving TIMP-1, leading to downstream expression of metastasis-promoting genes [97, 98].

However, HGF signalling is not unidirectional. A high level of bi-directional crosstalk between tumour cells and stromal cells, in particular fibroblasts, has been reported. Nakamura and colleagues have reported the expression of HGF inducers in several carcinoma cell lines, including squamous cell carcinoma, human epidermoid carcinoma, human non-small cell lung cancer cells, human cholangiocarcinoma cells, and SBC-3 human small cell lung carcinoma cells [99]. These HGF inducers include interleukin (IL)-1 $\beta$, FGF, PDGF and TGF- $\alpha$ and were reported to up-regulate HGF expression by stromal fibroblasts $[99,100]$. Taken together, these studies highlight that HGF and aberrant c-MET signalling have a critical role in mediating the bi-directional crosstalk between HSC and tumour cells during hepatocarcinogenesis. 


\section{Transforming growth factor- $\beta$}

The large latent TGF- $\beta$ complex is secreted by most cell types, including human HSC and hepatocytes [101, 102] and fixed in the ECM by transglutaminase-dependent linkage of latent TGF- $\beta$ binding protein to fibronectin and other ECM proteins, forming a reservoir of latent TGF- $\beta$. In the context of HCC, it has been suggested that defective TGF- $\beta$ signalling promotes tumourigenesis secondary to reduced responsiveness to the anti-proliferative effects of TGF- $\beta$ signalling $[103,104]$. However, TGF- $\beta$ appears to exhibit multiple roles in HCC pathogenesis. Tumour-suppressor functions are observed in the early stages of liver damage and regeneration, whereas during cancer progression, TGF- $\beta$ may exacerbate tumour invasiveness and metastatic behavior [105]. It has further been demonstrated that TGF- $\beta$ and PDGF signaling crosstalk supports EMT and is crucial for tumour growth and the acquisition of an invasive phenotype [106].

The survival and malignancy of HCC cell lines, including Huh7 and HepG2, have been reported to require autocrine TGF- $\beta$ signalling, with exogenous TGF- $\beta$ leading to growth inhibition of HCC cells [107]. Utilising HCC cell lines, Meindl-Beinker et al. revealed a heterogeneic response to TGF- $\beta$, reflective of different stages and mechanisms of disease. Variation between cell lines in their endogenous TGF- $\beta$ and Smad7 levels, and their transcriptional activity of Smad3, was related to the maintenance of TGF- $\beta$ cytostatic activity. In particular, the Hep3B, HepG2 and PLC hepatoma cell lines were found to have low TGF- $\beta$ and Smad7 levels and strong Smad3 transcriptional activity and were thus sensitive to TGF- $\beta$ cytostatic activity, representative of the early stages of chronic liver disease [108]. In an analysis of TGF- $\beta$ gene expression in HCC patients, Coulouarn et al. reported that those tumours displaying an invasive phenotype and increased recurrence were characterized by a late TGF- $\beta$ signalling signature, with transcriptional activation of genes associated with matrix remodelling and cell adhesion [109].

Therefore, as the role of TGF- $\beta$ in HCC pathogenesis appears to be highly context-dependent, exhibiting both pro- and anti-tumoural activity, it is highly unlikely that pan-TGF- $\beta$ blockade will provide a useful therapeutic avenue in HCC treatment. More selective strategies to interfere with TGF- $\beta$ signalling, perhaps even at a cellspecific level, will likely be required to modulate this signalling pathway for therapeutic gain in the context of HCC.

\section{Epiregulin}

The gut microbiome is increasingly recognized as a powerful modulator of fibrosis, cirrhosis, and infectious complications in chronic liver disease. Much interest is currently focused on the translocation of bacterial pathogen-associated molecular patterns (PAMPs), which activate inflammatory responses through Toll-like receptors (TLRs). Recently Dapito et al. demonstrated that Tlr4mut mice (harbouring non-functional TLR4) that received diethylnitrosamine (DEN) and $\mathrm{CCl}_{4}$ show 80-90 \% reduction in HCC tumour size and number, compared with mice expressing wild-type TLR4 [110]. Gut sterilisation significantly reduced this effect whereas LPS treatment enhanced it, suggesting a role for the LPSTLR4 pathway in promotion of hepatocarcinogenesis. Interestingly, alongside hepatocytes, HSC were identified as candidates for TLR4-dependent tumour promotion in the chronically injured liver. LPS and the gut microbiome were found to induce HSC activation, resulting in production of the mitogens HGF and epiregulin, which likely act on malignant hepatocytes. Epiregulin is a member of the EGF family, and results in EGF receptor and human epidermal growth factor receptor 2 activation during early stages of $\mathrm{DEN} / \mathrm{CCl}_{4}$ carcinogenesis, whereas it reduces hepatocyte apoptosis by NF-KB nuclear translocation during later stages $[110,111]$. This suggests that there may be merit in evaluating whether long-term antibiotic treatment confers any protection against HCC development. This could initially be investigated by following up patients with cirrhosis on long-term prophylaxis for spontaneous bacterial peritonitis or encephalopathy, although identifying a comparable control group may prove challenging.

\section{HSC and angiogenesis}

Angiogenesis has a critical role in HCC initiation, progression and metastasis, as reflected by the efficacy of sorafenib, which targets this process. The rapid growth pattern of malignant hepatocytes requires new vessel formation, stimulated by multiple pro-angiogenic factors. This pro-angiogenic environment in turn supports tumour progression and metastasis. The relevance of tumour vascularity is reinforced by the observation that VEGF expression progressively increases from lowgrade dysplasia to early-stage HCC [112]. VEGF overexpression is also associated with high tumour grade, and vascular and portal vein invasion [113-117]. Furthermore, raised plasma VEGF and angiopoietin 2 (Ang-2) are independent predictors of poor prognosis in advanced HCC [118].

HSC are known to secrete VEGF as well as other angiogenic factors including PDGF, MMPs, FGF, TGF- $\beta 1$, EGF, angiopoietin-1 (Ang-1) and Ang-2 [119-121]. Upon activation, HSC express multiple smooth muscle cell markers, suggesting they may act like pericytes during angiogenesis $[122,123]$. They also express angiogenic growth factor receptors, such as VEGF receptor, PDGF receptor and Tie-2 [124-126]. In liver injury and $\mathrm{HCC}$, this facilitates reciprocal signalling between HSC and endothelial cells or malignant hepatocytes and 
contributes towards a pro-angiogenic microenvironment. VEGF secretion by HSC can be hormonally induced by leptin, or by physical stress such as hypoxia, and is upregulated in HCC $[120,124,127]$. VEGF receptor upregulation also occurs during HSC activation, resulting in increased mitogenesis in response to VEGF [13].

Conditioned media from HCC cells can activate HSC and stimulate VEGF production. Coulouarn et al. cocultured LX2 cells with HepRG HCC cells, and analysis of differential gene expression identified a gene network linked to VEGFA and MMP9 [128]. This was shown to promote angiogenesis, as conditioned medium from LX2-HepaRG coculture (but not LX2 or HepaRG medium alone) induced tubule complex formation by primary human umbilical vein endothelial cells. A gene signature of this cross-talk correlated with poor prognosis and metastasis in humans [128].

Lin et al. have also shown increased angiogenesis by activated HSC in vitro using a murine $\mathrm{HCC}$ cell line (H22) and rat colon microvascular endothelial cells [129]. They went on to demonstrate in vivo, using an orthotopic HCC model, that activated HSCs promote tumour vascularisation via increased VEGF and possibly PDGF secretion.

Of particular interest in $\mathrm{HCC}$ is the interaction between malignant hepatocytes, endothelial cells and activated HSC. Torimura et al. characterised expression of Ang-1, Ang-2 and Tie2 receptors in HCC cell lines
(HLE and HuH-7) and human HCC cases [130]. They concluded angiopoietin-Tie2 signalling in the vascular wall may act in favour of vessel remodelling in HCC. Ang-2 production by hepatoma cells, HSC and smooth muscle cells binds Tie2 (on HSC, smooth muscle and endothelial cells) and destabilises connections between endothelial cells, perivascular support cells and ECM. This allows exposure to VEGF, which in these relatively hypoxic conditions, is upregulated. Proliferation of endothelial cells ensues, allowing neovascularization and further tumour growth.

Recently, it has been shown that metformin inhibits angiogenesis in vitro, in an HCC (HepG2 line) and HSC (LX2) co-culture system [131]. This was associated with reduced VEGF production. It was postulated that metformin was acting via AMPK activation, and specifically targeting HSC in this model. Indeed, inhibition of AMPK on LX2 cells (but not on HepG2 cells) using siRNA did restore VEGF levels and abrogate metformin's anti-angiogenic effect. Metformin would seem a promising candidate for human HCC treatment, but unfortunately retrospective data would suggest a lack of survival benefit [132]. However, considering the well-established tolerability of metformin, its potential HSC-mediated effect on angiogenesis merits further investigation.

Some of the factors mediating crosstalk between HSC and HCC are summarised in Fig. 1.

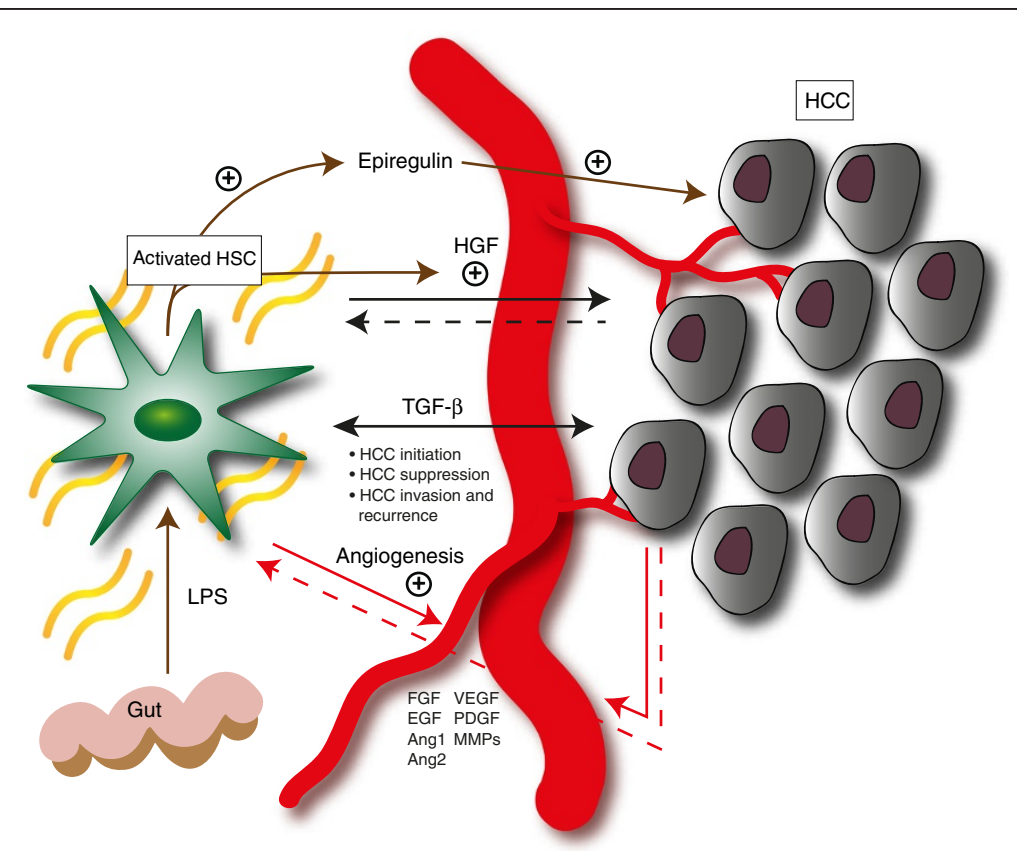

Fig. 1 Crosstalk between HSC and HCC. HSC-secreted factors such as HGF may promote hepatocarcinogenesis. Similarly, HCC signalling results in further HGF production from activated HSC. TGF- $\beta$ demonstrates both tumour-suppressive and tumour-promoting functions, depending on context. HSC produce angiogenic cytokines, supporting new vessel growth. HCC cells contribute to angiogenic signalling, and HSC also possess receptors for some of these factors. Gut-derived LPS induces HSC activation, resulting in epiregulin and HGF production, with mitogenic effects on HCC 


\section{HSC and immunomodulation}

Tumour immune evasion is now regarded as a hallmark of cancer progression and is therefore a very active area of research. One mechanism by which tumours evade the immune response is through the augmentation of the numbers and activity of immunosuppressive cells, at both the tumour site and within lymphoid organs [133]. Such cells include regulatory T-cells (Tregs) and myeloidderived suppressor cells (MDSC). Increased levels of Tregs within peripheral blood and tumours have been reported in human HCC cases, and have further been shown to suppress anti-tumour immune responses in addition to promoting angiogenic remodeling [134-136]. Further, intratumoural Treg accumulation has been reported to correlate with disease progression and poor prognosis [137]. MDSC are defined by the markers CD11b and Ly6$\mathrm{C} / \mathrm{G}$ and have been found in the tumour, lymph nodes and blood, suppressing cellular responses to cancer cells [138].

The immunosuppressive activities of HSC have only recently been recognised with studies demonstrating, both in vitro and in vivo, that activated HSC are able to strongly suppress $\mathrm{T}$-cell responses. Investigation into the divergent immunomodulatory activity of quiescent and intratumoural $\mathrm{HSC}$ has revealed that, in vitro, intratumoural HSC induce T-cell hyporesponsiveness, an effect not seen with quiescent HSC [139]. Moreover, in an orthotopic rat model of HCC, intratumoural HSC number strongly correlated with T-cell apoptosis and lung metastatic nodules [140]. Although a direct interaction was not reported, this does suggest an additional role for HSC in HCC metastasis via an immunosuppressive mechanism.
Co-transplantation of HCC cells and HSC into immunocompetent mice promoted $\mathrm{HCC}$ proliferation and enhanced tumour angiogenesis, in association with inhibition of lymphocyte infiltration and apoptosis of infiltrating monocytes [73]. In an orthotopic model of HCC, activated HSC in tumour-bearing mice significantly increase Treg and MDSC populations in the spleen and tumour stroma [141]. An increase in tumour vascular and lymphatic vessel density was also reported in those tumours co-transplanted with HSC.

Investigation into the mechanisms underlying HSC immunomodulatory effects in HCC has demonstrated that this may be mediated via upregulation of human B7 homolog 1 (B7-H1; programmed death ligand 1 (PDL-1)) on tumoural HSC [142-144]. B7-H1 can act as both receptor and ligand and has immunosuppressive functions such as promoting activated T-cell apoptosis and inhibiting T-cell-mediated tumour cell apoptosis $[1,145,146]$. Its counter-receptor, PD-1, is expressed on activated, but not resting, T-cells, B-cells and monocytes [2]. B7-H1/PD-1 signaling has been reported to promote Treg cell induction and immunosuppressive function through the down-regulation of mTOR and AKT phosphorylation [147, 148]. In vitro experiments involving incubation of T-cells with antiB7-H1 monoclonal antibody resulted in a significant reduction in HSC immunomodulatory activity and HCC migration and invasion [139].

Three monoclonal antibodies against PD-1, and one against B7-H1 have been developed and promising Phase 1 data has been reported [149]. In one study, varying degrees of tumour regression were found in colon, renal



Fig. 2 Immunomodulatory effects of HSC in HCC. Intratumoural HSC (iHSC) promote HCC progression through i) an increase in Treg cell induction and immunosuppressive function and ii) upregulation of $\mathrm{B} 7-\mathrm{H} 1$ on $\mathrm{H} H \mathrm{HC}$ resulting in increased ligation of its receptor (PD-1) on activated T-cells, leading to increased apoptosis of activated T cells with subsequent inhibition of T-cell-mediated tumour cell apoptosis. This results in HCC immunotolerance and a permissive environment for tumour growth. PD-1, programmed death ligand; B7-H1 human B7 homolog 1; ECM, extracellular matrix 
and lung cancers and melanoma and a significant increase in tumour lymphocyte infiltration was noted [150]. This has been extended to a second clinical trial where responses were seen in 16 out of 39 patients with advanced melanoma [151]. These early clinical studies further demonstrated encouraging safety data. In the context of HCC, a Phase 1, dose escalation study investigating the effects of anti-PD-1 therapy is currently underway in patients with advanced HCC (NCT01658878), however results have yet to be reported. Some of the immunomodulatory effects of HSC in HCC are summarised in Fig. 2.

Therapeutic approaches to targeting HSC and HSC signalling HSC represent a small percentage of cells within the liver, and specific therapeutic targeting of HSC remains challenging. Recently, transgenic mice have been developed that allow reliable fluorescent labeling or genetic manipulation in HSC and myofibroblasts [152, 153].
These transgenic mice will hopefully prove useful not only in elucidating the molecular mechanisms in HSC that regulate the stroma-HCC interface, but also in facilitating the identification of rational, new therapeutic targets in hepatocarcinogenesis.

If a targetable, HSC-dependent pathway driving hepatocarcinogenesis is identified, cell-specific therapy is conceivable, albeit not entirely straightforward. ECM homeostasis is a key physiological process and modifying HSC functions may impair this, with potential for severe adverse effects. Practically, delivering drugs to HSC is hindered by a lack of multiple transport receptors and endocytic capacity. Furthermore, candidate compounds may include siRNA and cytokines, which have a short half-life in plasma following systemic administration, hindering therapeutic efficacy [154].

To overcome these problems, a number of groups have explored active targeting of HSC to deliver therapeutic

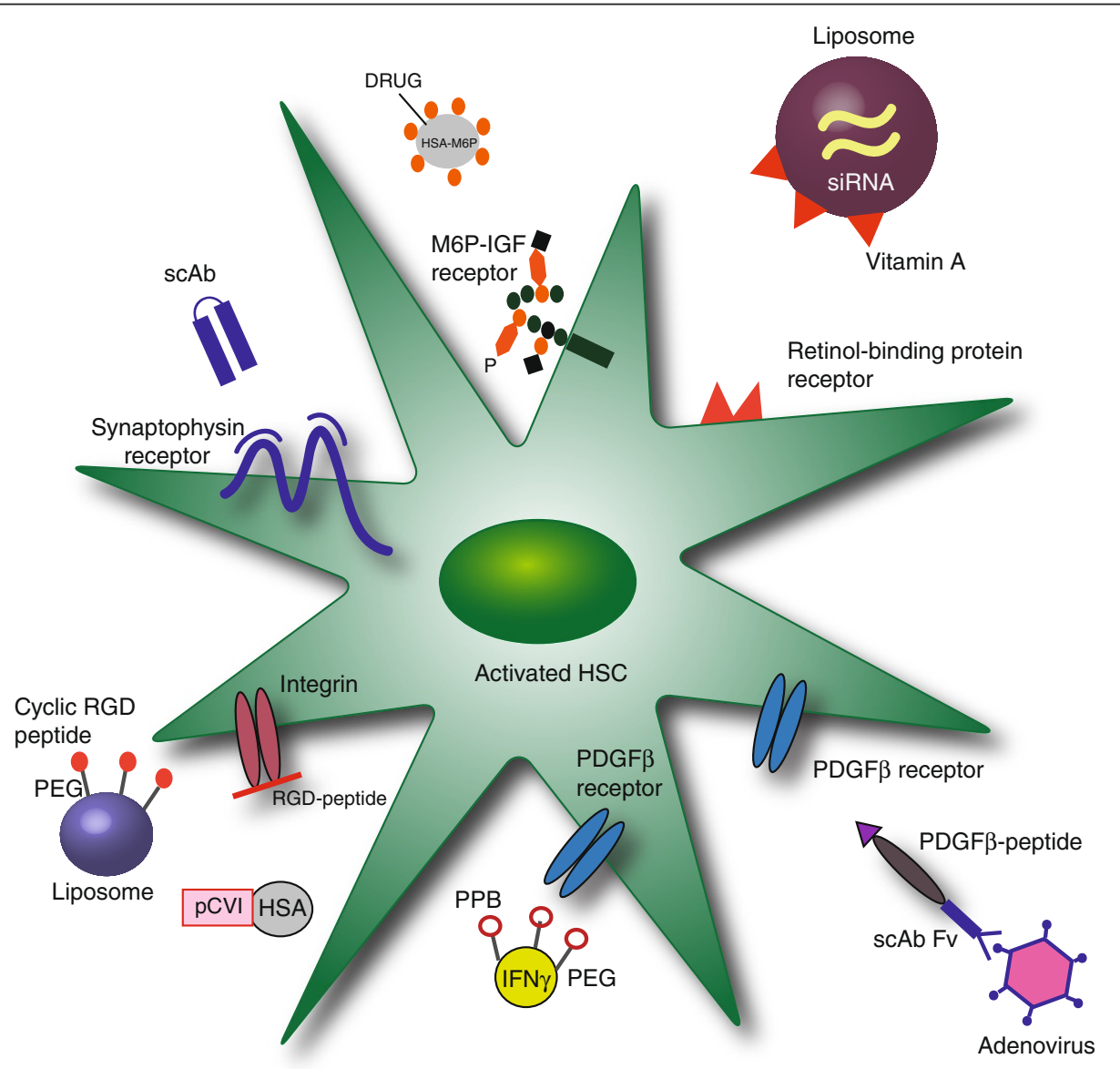

Fig. 3 Therapeutic approaches to targeting HSC. HSC have been targeted by coupling a compound to a carrier possessing either a HSC-specific receptor-binding ligand or an antibody. Carriers utilised include: a monoclonal human single chain antibody (scAb) fragment to synaptophysin [155]; a sugar moiety that binds the mannose-6-phosphate (M6P) insulin-like growth factor receptor [157]; a liposome specific to the vitamin A (retinol-binding protein) receptor [156]; PDGFß-peptide [160]; PDGF $\beta$ receptor recognising peptide (PPB) [164]; an RGD peptide bound to a liposome or coupled to human serum albumin (HSA) [159, 162] scAb FV, single chain antibody variable fragment; PEG, polyethylene glycol; pCVI, 10 cyclic peptide moieties that recognise collagen type $\mathrm{VI}$ receptors 
compounds. This involves coupling the selected compound to a carrier possessing a specific receptor-binding ligand, or an antibody.

Carriers recently employed have included an antibody to the synaptophysin receptor on HSC, and a liposome specific to the vitamin A receptor on HSC [155, 156]. Furthermore Poelstra et al. have used proteins substituted with a sugar moiety that binds the mannose-6-phosphateIGFII receptor [157]. They have also utilised a peptide that binds the PDGF receptor- $\beta$, [158] to deliver a protein or an adenovirus to HSC $[159,160]$. An RGD-peptide which binds to RGD-binding integrins has also been used to create a carrier that accumulates in HSC [161, 162]. Of note, the carrier molecules used must fit strict criteria such as low immunogenicity, and high stability, biocompatibility and selectivity, if they are to translate into clinical practice. Moreover, the target receptors on HSC should be selectively expressed and ideally upregulated during disease activity. A further challenge is the requirement for endocytosis of the construct following target receptor binding. This can be particularly problematic in the case of biological therapeutics, which usually fail to withstand the endosomal degradation process.

With these challenges in mind, Bansal et al. subsequently developed a recombinant protein construct to deliver interferon gamma (IFNY) to HSC [163]. This elegant system transported the signalling moiety of IFN $\gamma$ to the PDGF-receptor with a carrier molecule that was simplified and miniaturised. They found that IFNY could be effectively delivered to human HSC in vitro, and to mouse HSC in vivo. Furthermore, the targeted fusion proteins were shown to ameliorate hepatic fibrosis in $\mathrm{CCl}_{4}$-treated mice [163-165]. This suggests that directing a cytokine to HSC is a feasible and potentially tractable therapeutic approach, both in the context of developing new treatments for patients with liver fibrosis, as well as HCC. Therapeutic approaches to targeting HSC are summarised in Fig. 3.

\section{Conclusions}

Treatment options for HCC are still severely limited. Recently, increasing evidence has suggested that HSC are key regulators of hepatocarcinogenesis, likely through a variety of mechanisms, including direct effects on malignant hepatocytes, and indirectly via modulation of the peri-tumoural stroma and immune response. Further elucidation of the molecular mechanisms underpinning the crosstalk between the HSC, stromal and tumoural compartments will hopefully allow multi-faceted and personalized treatment of HCC in the future. For example, agents with a direct anti-tumoural effect could be combined with therapies that inhibit HSC-mediated angiogenesis and fibrogenesis. What has become increasingly clear is that neither the tumour nor the microenvironment can be viewed in isolation, rather that successful HCC therapies will need to be directed at counteracting the synergistic components of this complex relationship.

\section{Abbreviations}

B7-H1: human B7 homolog 1; CAF: Cancer-associated fibroblasts;

$\mathrm{CCl}_{4}$ : Carbon tetrachloride; DEN: Diethylnitrosamine; ECM: Extracellular matrix; EGF: Epidermal growth factor; EMT: Epithelial-mesenchymal-transition; FAK: Focal adhesion kinase; FGF: Fibroblast growth factor;

HCC: Hepatocellular carcinoma; HGF: Hepatocyte growth factor; HSC: Hepatic stellate cells; IFNY: Interferon gamma; IGF: Insulin-like growth factor; iHSC: Intratumoural HSC; IL: Interleukin; MMPs: Matrix metalloproteinases; MDSC: Myeloid-derived suppressor cells; PAMPs: Pathogen-associated molecular patterns; PI3K: Phosphatidylinositol 3-kinase; PDGF: Platelet-derived growth factor; PDL-1: Programmed death ligand 1; TLRs: Toll-like receptors; TGF- $\beta$ : Transforming growth factor-beta; TIMP-1: Tissue inhibitors of metalloproteinases 1; Tregs: Regulatory T-cells; VEGF: Vascular endothelial growth factor.

\section{Competing interests}

The authors declare that they have no competing interests. Author Contributions AIT, KPC and NCH conceived, designed and wrote the manuscript. All authors read and approved the final manuscript.

\section{Authors' information}

Alexandra and Kylie are first joint authors.

\section{Acknowledgements}

The authors acknowledge the support of Cancer Research UK and the Wellcome Trust.

Received: 4 March 2015 Accepted: 15 May 2015

Published online: 27 May 2015

\section{References}

1. Azuma T, Yao S, Zhu G, Flies AS, Flies SJ, Chen L. B7-H1 is a ubiquitous antiapoptotic receptor on cancer cells. Blood. 2008;111:3635-43.

2. Keir ME, Butte MJ, Freeman GJ, Sharpe AH. PD-1 and its ligands in tolerance and immunity. Annu Rev Immunol. 2008;26:677-704.

3. Globocan.larc.Fr [http://globocan.iarc.fr]

4. Forner A, Llovet JM, Bruix J. Hepatocellular carcinoma. Lancet. 2012;379:1245-55

5. Bruix J, Sherman M, American Association for the Study of Liver Diseases: Management of hepatocellular carcinoma: an update. Hepatology 2011;53(3):1020-1022.

6. European Association For The Study Of The Liver, European Organisation For Research And Treatment Of Cancer: EASL-EORTC clinical practice guidelines: management of hepatocellular carcinoma. J Hepatol 2012;53(3):908-943

7. Straussman R, Morikawa T, Shee K, Barzily-Rokni M, Qian ZR, Du J, et al. Tumour micro-environment elicits innate resistance to RAF inhibitors through HGF secretion. Nature. 2012;487:500-4.

8. Henderson NC, Iredale JP. Liver fibrosis: cellular mechanisms of progression and resolution. Clin Sci. 2007;112:265-80.

9. Hoshida Y, Villanueva A, Kobayashi M, Peix J, Chiang DY, Camargo A, et al. Gene expression in fixed tissues and outcome in hepatocellular carcinoma. N Engl J Med. 2008:359:1995-2004.

10. Seitz HK, Stickel F. Risk factors and mechanisms of hepatocarcinogenesis with special emphasis on alcohol and oxidative stress. Biol Chem. 2006:387:349-60

11. Llovet JM, Ricci S, Mazzaferro V, Hilgard P, Gane E, Blanc J-F, et al. SHARP Investigators Study Group: Sorafenib in advanced hepatocellular carcinoma. N Engl J Med. 2008;359:378-90.

12. Zhou X, Jamil A, Nash A, Chan J, Trim N, Iredale JP, et al. Impaired proteolysis of collagen I inhibits proliferation of hepatic stellate cells: implications for regulation of liver fibrosis. J Biol Chem. 2006;281:39757-65.

13. Friedman SL. Hepatic stellate cells: protean, multifunctional, and enigmatic cells of the liver. Physiol Rev. 2008;88:125-72.

14. Lok AS, Seeff LB, Morgan TR, di Bisceglie AM, Sterling RK, Curto TM, et al. HALT-C Trial Group: Incidence of hepatocellular carcinoma and associated risk factors in hepatitis C-related advanced liver disease. Gastroenterology. 2009;136:138-48. 
15. Zhang DY, Friedman SL. Fibrosis-dependent mechanisms of hepatocarcinogenesis. Hepatology. 2012;56:769-75.

16. Bhowmick NA, Neilson EG, Moses HL. Stromal fibroblasts in cancer initiation and progression. Nature. 2004;432:332-7.

17. Olumi AF, Grossfeld GD, Hayward SW, Carroll PR, TIsty TD, Cunha GR. Carcinoma-associated fibroblasts direct tumor progression of initiated human prostatic epithelium. Cancer Res. 1999;59:5002-11.

18. Wang W, Li Q, Yamada T, Matsumoto K, Matsumoto I, Oda M, et al. Crosstalk to stromal fibroblasts induces resistance of lung cancer to epidermal growth factor receptor tyrosine kinase inhibitors. Clin Cancer Res. 2009:15:6630-8.

19. Eberlein C, Rooney C, Ross SJ, Farren M, Weir HM, Barry ST: E-Cadherin and EpCAM expression by NSCLC tumour cells associate with normal fibroblast activation through a pathway initiated by integrin av $\beta 6$ and maintained through TGF $\beta$ signalling. Oncogene 2014;34:704.

20. Hernandez-Gea V, Toffanin S, Friedman SL, Llovet JM. Role of the microenvironment in the pathogenesis and treatment of hepatocellular carcinoma. Gastroenterology. 2013;144:512-27.

21. Jedeszko C, Victor BC, Podgorski I, Sloane BF. Fibroblast hepatocyte growth factor promotes invasion of human mammary ductal carcinoma in situ. Cancer Res. 2009;69:9148-55.

22. Busch S, Acar A, Magnusson Y, Gregersson P, Rydén L, Landberg G: TGF-beta receptor type-2 expression in cancer-associated fibroblasts regulates breast cancer cell growth and survival and is a prognostic marker in pre-menopausal breast cancer. Oncogene 2013;34:704.

23. Patocs A, Zhang L, Xu Y, Weber F, Caldes T, Mutter GL, et al. Breast-cancer stromal cells with TP53 mutations and nodal metastases. N Engl J Med. 2007;357:2543-51.

24. Nakagawa H, Liyanarachchi S, Davuluri RV, Auer H, Martin EW, LaChapellede A, et al. Role of cancer-associated stromal fibroblasts in metastatic colon cancer to the liver and their expression profiles. Oncogene. 2004;23:7366-77.

25. Noskova V, Ahmadi S, Asander E, Casslén B. Ovarian cancer cells stimulate UPA gene expression in fibroblastic stromal cells via multiple paracrine and autocrine mechanisms. Gynecol Oncol. 2009;115:121-6.

26. Bataller R, Brenner DA. Liver fibrosis. J Clin Invest. 2005;115:209-18.

27. Druker BJ. Inhibition of the Bcr-Abl tyrosine kinase as a therapeutic strategy for CML. Oncogene. 2002;21:8541-6.

28. O'Brien SG, Guilhot F, Larson RA, Gathmann I, Baccarani M, Cervantes F, et al. IRIS Investigators: Imatinib compared with interferon and low-dose cytarabine for newly diagnosed chronic-phase chronic myeloid leukemia. N Engl J Med. 2003;348:994-1004.

29. Luo J, Solimini NL, Elledge SJ. Principles of cancer therapy: oncogene and non-oncogene addiction. Cell. 2009;136:823-37.

30. Chapman PB, Hauschild A, Robert C, Haanen JB, Ascierto P, Larkin J, et al. BRIM-3 Study Group: Improved survival with vemurafenib in melanoma with BRAF V600E mutation. N Engl J Med. 2011:364:2507-16.

31. Wilson TR, Fridlyand J, Yan Y, Penuel E, Burton L, Chan E, et al. Widespread potential for growth-factor-driven resistance to anticancer kinase inhibitors. Nature. 2012;487:505-9.

32. Faouzi $S$, Le Bail B, Neaud V, Boussarie L, Saric J, Bioulac-Sage P, et al. Myofibroblasts are responsible for collagen synthesis in the stroma of human hepatocellular carcinoma: an in vivo and in vitro study. J Hepatol. 1999;30:275-84.

33. Le Bail B, Faouzi S, Boussarie L, Guirouilh J, Blanc JF, Carles J, et al. Osteonectin/SPARC is overexpressed in human hepatocellular carcinoma. J Pathol. 1999;189:46-52.

34. Dubuisson L, Lepreux S, Bioulac-Sage P, Balabaud C, Costa AM, Rosenbaum J, et al. Expression and cellular localization of fibrillin-1 in normal and pathological human liver. J Hepatol. 2001;34:514-22.

35. Park YN, Yang CP, Cubukcu O, Thung SN, Theise ND. Hepatic stellate cell activation in dysplastic nodules: evidence for an alternate hypothesis concerning human hepatocarcinogenesis. Liver. 1997;17:271-4.

36. Théret $N$, Musso $O$, Turlin $B$, Lotrian D, Bioulac-Sage $P$, Campion JP, et al. Increased extracellular matrix remodeling is associated with tumor progression in human hepatocellular carcinomas. Hepatology. 2001;34:82-8.

37. Nishio T, limuro $Y$, Nitta T, Harada N, Yoshida M, Hirose T, et al. Increased expression of collagenase in the liver induces hepatocyte proliferation with cytoplasmic accumulation of beta-catenin in the rat. J Hepatol. 2003:38:468-75.

38. You J, Park S-A, Shin D-S, Patel D, Raghunathan VK, Kim M, et al. Characterizing the effects of heparin gel stiffness on function of primary hepatocytes. Tissue Eng Part A. 2013;19:2655-63.
39. Semler EJ, Lancin PA, Dasgupta A, Moghe PV. Engineering hepatocellular morphogenesis and function via ligand-presenting hydrogels with graded mechanical compliance. Biotechnol Bioeng. 2005;89:296-307.

40. Schrader J, Gordon-Walker TT, Aucott RL, van Deemter M, Quaas A, Walsh S, et al. Matrix stiffness modulates proliferation, chemotherapeutic response, and dormancy in hepatocellular carcinoma cells. Hepatology. 2011:53:1192-205.

41. Wells RG. The role of matrix stiffness in regulating cell behavior. Hepatology. 2008:47:1394-400

42. Li Z, Dranoff JA, Chan EP, Uemura M, Sévigny J, Wells RG. Transforming growth factor-beta and substrate stiffness regulate portal fibroblast activation in culture. Hepatology. 2007;46:1246-56.

43. Masuzaki R, Tateishi R, Yoshida H, Goto E, Sato T, Ohki T, et al. Prospective risk assessment for hepatocellular carcinoma development in patients with chronic hepatitis C by transient elastography. Hepatology. 2009;49:1954-61.

44. Kim DY, Song KJ, Kim SU, Yoo EJ, Park JY, Ahn SH, et al. Transient elastography-based risk estimation of hepatitis B virus-related occurrence of hepatocellular carcinoma: development and validation of a predictive model. Onco Targets Ther. 2013;6:1463-9.

45. Wong GL-H, Chan HL-Y, Wong CK-Y, Leung C, Chan CY, Ho PP-L, et al. Liver stiffness-based optimization of hepatocellular carcinoma risk score in patients with chronic hepatitis B. J Hepatol. 2014;60:339-45.

46. Singh S, Fujii LL, Murad MH, Wang Z, Asrani SK, Ehman RL, et al. Liver stiffness is associated with risk of decompensation, liver cancer, and death in patients with chronic liver diseases: a systematic review and meta-analysis. Clin Gastroenterol Hepatol. 2013;11:1573-84. e1-2- quiz e88-9.

47. Masuzaki R, Tateishi R, Yoshida H, Sato T, Ohki T, Goto T, et al. Assessing liver tumor stiffness by transient elastography. Hepatol Int. 2007:1:394-7.

48. Levental KR, Yu H, Kass L, Lakins JN, Egeblad M, Erler JT, et al. Matrix crosslinking forces tumor progression by enhancing integrin signaling. Cell. 2009;139:891-906

49. Legate KR, Wickström SA, Fässler R. Genetic and cell biological analysis of integrin outside-in signaling. Genes Dev. 2009;23:397-418.

50. Desgrosellier JS, Cheresh DA. Integrins in cancer: biological implications and therapeutic opportunities. Nat Rev Cancer. 2010;10:9-22.

51. Reif S, Lang A, Lindquist JN, Yata Y, Gäbele E, Scanga A, et al. The role of focal adhesion kinase-phosphatidylinositol 3-kinase-akt signaling in hepatic stellate cell proliferation and type I collagen expression. J Biol Chem. 2003:278:8083-90.

52. Dong Y, Xie X, Wang Z, Hu C, Zheng Q, Wang Y, et al. Increasing matrix stiffness upregulates vascular endothelial growth factor expression in hepatocellular carcinoma cells mediated by integrin $\beta 1$. Biochem Biophys Res Commun. 2014:444:427-32

53. Lee SK, Kim M-H, Cheong JY, Cho SW, Yang S-J, Kwack K. Integrin alpha V polymorphisms and haplotypes in a Korean population are associated with susceptibility to chronic hepatitis and hepatocellular carcinoma. Liver Int. 2009;29:187-95.

54. Lai KKY, Shang S, Lohia N, Booth GC, Masse DJ, Fausto N, et al. Extracellular matrix dynamics in hepatocarcinogenesis: a comparative proteomics study of PDGFC transgenic and Pten null mouse models. PLoS Genet. 2011;7, e1002147.

55. Jung CW, Song T-J, Lee K-O, Choi SB, Kim WB, Suh SO, et al. Characterization of hepatocellular carcinoma cell lines based on cell adhesion molecules. Int J Mol Med. 2012:29:1158-64.

56. Giannelli G, Bergamini C, Fransvea E, Marinosci F, Quaranta V, Antonaci S. Human hepatocellular carcinoma $(\mathrm{HCC})$ cells require both alpha3beta1 integrin and matrix metalloproteinases activity for migration and invasion. Lab Invest. 2001;81:613-27.

57. Torimura T, Ueno T, Kin M, Harad R, Nakamura T, Sakamoto M, et al. Laminin deposition to type IV collagen enhances haptotaxis, chemokinesis, and adhesion of hepatoma cells through beta1-integrins. J Hepatol. 2001;35:245-53.

58. Yang C, Zeisberg M, Lively JC, Nyberg P, Afdhal N, Kalluri R. Integrin alpha1beta1 and alpha2beta1 are the key regulators of hepatocarcinoma cell invasion across the fibrotic matrix microenvironment. Cancer Res. 2003;63:8312-7.

59. Zhao G, Cui J, Qin Q Zhang J, Liu L, Deng S, et al. Mechanical stiffness of liver tissues in relation to integrin $\beta 1$ expression may influence the development of hepatic cirrhosis and hepatocellular carcinoma. J Surg Oncol. 2010;102:482-9.

60. Fu B-H, Wu Z-Z, Qin J. Effects of integrin a6ß1 on migration of hepatocellular carcinoma cells. Mol Biol Rep. 2011;38:3271-6. 
61. Mizuno H, Ogura M, Saito Y, Sekine W, Sano R, Gotou T, et al. Changes in adhesive and migratory characteristics of hepatocellular carcinoma (HCC) cells induced by expression of alpha3beta1 integrin. Biochim Biophys Acta. 1780;2008:564-70.

62. Sil H, Sen T, Chatterjee A. Fibronectin-integrin (alpha5beta1) modulates migration and invasion of murine melanoma cell line B16F10 by involving MMP-9. Oncol Res. 2011;19:335-48.

63. Jing $Y$, Jia $D$, Wong C-M, Oi-Lin Ng I, Zhang Z, Liu L, et al. SERPINA5 inhibits tumor cell migration by modulating the fibronectin-integrin $\beta 1$ signaling pathway in hepatocellular carcinoma. Mol Oncol. 2014:8:366-77.

64. Nguyen TV, Sleiman M, Moriarty T, Herrick WG, Peyton SR. Sorafenib resistance and JNK signaling in carcinoma during extracellular matrix stiffening. Biomaterials. 2014;35:5749-59.

65. Ke A-W, Shi G-M, Zhou J, Huang X-Y, Shi Y-H, Ding Z-B, et al. CD151 amplifies signaling by integrin a6ß1 to PI3K and induces the epithelial-mesenchymal transition in HCC cells. Gastroenterology. 2011;140:1629-41. e15.

66. Fransvea E, Mazzocca A, Antonaci S, Giannelli G. Targeting transforming growth factor (TGF)-betaRI inhibits activation of beta1 integrin and blocks vascular invasion in hepatocellular carcinoma. Hepatology. 2009;49:839-50.

67. Giannelli G, Fransvea E, Marinosci F, Bergamini C, Colucci S, Schiraldi O, et al. Transforming growth factor-beta1 triggers hepatocellular carcinoma invasiveness via alpha3beta1 integrin. Am J Pathol. 2002;161:183-93.

68. Kim H-P, Kim T-Y, Lee M-S, Jong H-S, Kim T-Y, Lee JW, et al. TGF-beta1-mediated activations of c-Src and Rac1 modulate levels of cyclins and p27(Kip1) CDK inhibitor in hepatoma cells replated on fibronectin. Biochim Biophys Acta. 1743;2005:151-61.

69. Matsuzaki K. Smad phosphoisoform signals in acute and chronic liver injury: similarities and differences between epithelial and mesenchymal cells. Cell Tissue Res. 2012;347:225-43.

70. Hayashida T. Integrins modulate cellular fibrogenesis at multiple levels; Regulation of TGF- $\beta$ signaling. Endocr Metab Immune Disord Drug Targets. 2010;10:302-19.

71. Cai T, Lei QY, Wang LY, Zha XL. TGF-beta 1 modulated the expression of alpha 5 beta 1 integrin and integrin-mediated signaling in human hepatocarcinoma cells. Biochem Biophys Res Commun. 2000;274:519-25.

72. Amann T, Bataille F, Spruss T, Mühlbauer M, Gäbele E, Schölmerich J, et al. Activated hepatic stellate cells promote tumorigenicity of hepatocellular carcinoma. Cancer Sci. 2009;100:646-53.

73. Zhao W, Zhang L, Yin Z, Su W, Ren G, Zhou C, et al. Activated hepatic stellate cells promote hepatocellular carcinoma development in immunocompetent mice. Int J Cancer. 2011;129:2651-61.

74. Jia C-C, Wang T-T, Liu W, Fu B-S, Hua X, Wang G-Y, et al. Cancer-associated fibroblasts from hepatocellular carcinoma promote malignant cell proliferation by HGF secretion. PLoS One. 2013;8, e63243.

75. Sun B, Zhang X, Cheng X, Zhang Y, Chen L, Shi L, et al. Intratumoral hepatic stellate cells as a poor prognostic marker and a new treatment target for hepatocellular carcinoma. PLoS One. 2013;8, e80212.

76. Santamato A, Fransvea E, Dituri F, Caligiuri A, Quaranta M, Niimi T, et al. Hepatic stellate cells stimulate HCC cell migration via laminin-5 production. Clin Sci. 2011;121:159-68.

77. Guirouilh J, Castroviejo M, Balabaud C, Desmoulière A, Rosenbaum J. Hepatocarcinoma cells stimulate hepatocyte growth factor secretion in human liver myofibroblasts. Int J Oncol. 2000;17:777-81.

78. Guirouilh J, Le Bail B, Boussarie L, Balabaud C, Bioulac-Sage P, Desmoulière $A$, et al. Expression of hepatocyte growth factor in human hepatocellular carcinoma. J Hepatol. 2001;34:78-83.

79. Efimova EA, Glanemann M, Liu L, Schumacher G, Settmacher U, Jonas S, et al. Effects of human hepatocyte growth factor on the proliferation of human hepatocytes and hepatocellular carcinoma cell lines. Eur Surg Res. 2004;36:300-7.

80. Monvoisin A, Neaud V, De Lédinghen V, Dubuisson L, Balabaud C, Bioulac-Sage $P$, et al. Direct evidence that hepatocyte growth factor-induced invasion of hepatocellular carcinoma cells is mediated by urokinase. J Hepatol. 1999;30:511-8.

81. Suzuki A, Hayashida M, Kawano H, Sugimoto K, Nakano T, Shiraki K. Hepatocyte growth factor promotes cell survival from fas-mediated cell death in hepatocellular carcinoma cells via Akt activation and Fas-death-inducing signaling complex suppression. Hepatology. 2000;32:796-802.

82. Schmidt C, Bladt F, Goedecke S, Brinkmann V, Zschiesche W, Sharpe M, et al Scatter factor/hepatocyte growth factor is essential for liver development. Nature. 1995;373:699-702.
83. Matsumoto K, Nakamura T. Hepatocyte growth factor and the Met system as a mediator of tumor-stromal interactions. Int J Cancer. 2006;119:477-83.

84. Suzuki K, Hayashi N, Yamada Y, Yoshihara H, Miyamoto $Y$, Ito $Y$, et al. Expression of the c-met protooncogene in human hepatocellular carcinoma. Hepatology. 1994;20:1231-6.

85. Kiss A, Wang NJ, Xie JP, Thorgeirsson SS. Analysis of transforming growth factor (TGF)-alpha/epidermal growth factor receptor, hepatocyte growth Factor/c-met, TGF-beta receptor type II, and p53 expression in human hepatocellular carcinomas. Clin Cancer Res. 1997;3:1059-66.

86. Breuhahn $K$, Longerich T, Schirmacher P. Dysregulation of growth factor signaling in human hepatocellular carcinoma. Oncogene. 2006;25:3787-800.

87. Boix L, Rosa JL, Ventura F, Castells A, Bruix J, Rodés J, et al. c-met mRNA overexpression in human hepatocellular carcinoma. Hepatology. 1994;19:88-91.

88. Okano J, Shiota G, Kawasaki H. Expression of hepatocyte growth factor (HGF) and HGF receptor (c-met) proteins in liver diseases: an immunohistochemical study. Liver. 1999;19:151-9.

89. Ueki T, Fujimoto J, Suzuki T, Yamamoto H, Okamoto E. Expression of hepatocyte growth factor and its receptor c-met proto-oncogene in hepatocellular carcinoma. Hepatology. 1997;25:862-6.

90. Kaposi-Novak P, Lee J-S, Gòmez-Quiroz L, Coulouarn C, Factor VM, Thorgeirsson SS. Met-regulated expression signature defines a subset of human hepatocellular carcinomas with poor prognosis and aggressive phenotype. J Clin Invest. 2006;116:1582-95.

91. Luedde T, Schwabe RF. NF-KB in the liver-linking injury, fibrosis and hepatocellular carcinoma. Nat Rev Gastroenterol Hepatol. 2011;8:108-18.

92. Date K, Matsumoto K, Kuba K, Shimura H, Tanaka M, Nakamura T. Inhibition of tumor growth and invasion by a four-kringle antagonist (HGF/NK4) for hepatocyte growth factor. Oncogene. 1998;17:3045-54.

93. Heideman DAM, Overmeer RM, van Beusechem WW, Lamers WH, Hakvoort TBM, Snijders PJF, et al. Inhibition of angiogenesis and HGF-CMET-elicited malignant processes in human hepatocellular carcinoma cells using adenoviral vector-mediated NK4 gene therapy. Cancer Gene Ther. 2005;12:954-62

94. Son G, Hirano T, Seki E, limuro Y, Nukiwa T, Matsumoto K, et al. Blockage of HGF/c-Met system by gene therapy (adenovirus-mediated NK4 gene) suppresses hepatocellular carcinoma in mice. J Hepatol. 2006;45:688-95.

95. Wright JH, Johnson MM, Shimizu-Albergine M, Bauer RL, Hayes BJ, Surapisitchat J, Hudkins KL, Riehle KJ, Johnson S, Yeh MM, Bammler TK, Beyer RP, Gilbertson DG, Alpers CC, Fausto N, Campbell JS: Paracrine activation of hepatic stellate cells in platelet-derived growth factor $C$ transgenic mice; evidence for stromal induction of hepatocellular carcinoma. Int J Cancer 2013;34:704.

96. Yu G, Jing Y, Kou X, Ye F, Gao L, Fan Q, et al. Hepatic stellate cells secreted hepatocyte growth factor contributes to the chemoresistance of hepatocellular carcinoma. PLoS One. 2013;8, e73312.

97. Kopitz C, Gerg M, Bandapalli OR, Ister D, Pennington CJ, Hauser S, et al Tissue inhibitor of metalloproteinases-1 promotes liver metastasis by induction of hepatocyte growth factor signaling. Cancer Res. 2007:67:8615-23

98. Schelter F, Grandl M, Seubert B, Schaten S, Hauser S, Gerg M, et al. Tumor cell-derived Timp-1 is necessary for maintaining metastasis-promoting Met-signaling via inhibition of Adam-10. Clin Exp Metastasis. 2011;28:793-802.

99. Nakamura T, Matsumoto K, Kiritoshi A, Tano Y, Nakamura T. Induction of hepatocyte growth factor in fibroblasts by tumor-derived factors affects invasive growth of tumor cells: in vitro analysis of tumor-stromal interactions. Cancer Res. 1997:57:3305-13.

100. Hasina R, Matsumoto K, Matsumoto-Taniura N, Kato I, Sakuda M, Nakamura T. Autocrine and paracrine motility factors and their involvement in invasiveness in a human oral carcinoma cell line. Br J Cancer. 1999;80:1708-17.

101. Meyer DH, Bachem MG, Gressner AM. Modulation of hepatic lipocyte proteoglycan synthesis and proliferation by Kupffer cell-derived transforming growth factors type beta 1 and type alpha. Biochem Biophys Res Commun. 1990;171:1122-9.

102. Roth S, Schurek J, Gressner AM. Expression and release of the latent transforming growth factor beta binding protein by hepatocytes from rat liver. Hepatology. 1997;25:1398-405.

103. Morris SM, Carter KT, Baek JY, Koszarek A, Yeh MM, Knoblaugh SE, et al. TGF- $\beta$ signaling alters the pattern of liver tumorigenesis induced by Pten inactivation. Oncogene. 2014 
104. Yang L, Inokuchi S, Roh YS, Song J, Loomba R, Park EJ, et al. Transforming growth factor- $\beta$ signaling in hepatocytes promotes hepatic fibrosis and carcinogenesis in mice with hepatocyte-specific deletion of TAK1. Gastroenterology. 2013;144:1042-54. e4.

105. Meindl-Beinker NM, Matsuzaki K, Dooley S. TGF- $\beta$ signaling in onset and progression of hepatocellular carcinoma. Dig Dis. 2012;30:514-23.

106. van Zijl F, Mair M, Csiszar A, Schneller D, Zulehner G, Huber H, et al. Hepatic tumor-stroma crosstalk guides epithelial to mesenchymal transition at the tumor edge. Oncogene. 2009;28:4022-33.

107. Mu X, Lin S, Yang J, Chen C, Chen Y, Herzig MC, et al. TGF- $\beta$ signaling is often attenuated during hepatotumorigenesis, but is retained for the malignancy of hepatocellular carcinoma cells. PLoS One. 2013;8, e63436.

108. Dzieran J, Fabian J, Feng T, Coulouarn C, Ilkavets I, Kyselova A, et al. Comparative analysis of TGF- $\beta / S$ mad signaling dependent cytostasis in human hepatocellular carcinoma cell lines. PLoS One. 2013;8, e72252.

109. Coulouarn C, Factor VM, Thorgeirsson SS. Transforming growth factor-beta gene expression signature in mouse hepatocytes predicts clinical outcome in human cancer. Hepatology. 2008;47:2059-67.

110. Dapito DH, Mencin A, Gwak G-Y, Pradere J-P, Jang M-K, Mederacke I, et al. Promotion of hepatocellular carcinoma by the intestinal microbiota and TLR4. Cancer Cell. 2012;21:504-16.

111. Darnaud M, Faivre J, Moniaux N. Targeting gut flora to prevent progression of hepatocellular carcinoma. J Hepatol. 2013;58:385-7.

112. Park YN, Kim YB, Yang KM, Park C. Increased expression of vascular endothelial growth factor and angiogenesis in the early stage of multistep hepatocarcinogenesis. Arch Pathol Lab Med. 2000;124:1061-5.

113. Yamaguchi $R$, Yano H, lemura A, Ogasawara S, Haramaki M, Kojiro M. Expression of vascular endothelial growth factor in human hepatocellular carcinoma. Hepatology. 1998;28:68-77.

114. Li XM, Tang ZY, Zhou G, Lui YK, Ye SL. Significance of vascular endothelial growth factor mRNA expression in invasion and metastasis of hepatocellular carcinoma. J Exp Clin Cancer Res. 1998;17:13-17.

115. Yao D-F, Wu X-H, Zhu Y, Shi G-S, Dong Z-Z, Yao D-B, et al. Quantitative analysis of vascular endothelial growth factor, microvascular density and their clinicopathologic features in human hepatocellular carcinoma. HBPD INT. 2005:4:220-6.

116. Zhou J, Tang ZY, Fan J, Wu ZQ, Li XM, Liu YK, et al. Expression of platelet-derived endothelial cell growth factor and vascular endothelial growth factor in hepatocellular carcinoma and portal vein tumor thrombus. J Cancer Res Clin Oncol. 2000;126:57-61.

117. Zhu AX, Duda DG, Sahani DV, Jain RK. HCC and angiogenesis: possible targets and future directions. Nat Rev Clin Oncol. 2011;8:292-301.

118. Llovet JM, Peña CEA, Lathia CD, Shan M, Meinhardt G, Bruix J. SHARP Investigators Study Group: Plasma biomarkers as predictors of outcome in patients with advanced hepatocellular carcinoma. Clin Cancer Res. 2012;18:2290-300.

119. Corpechot C, Barbu V, Wendum D, Kinnman N, Rey C, Poupon R, et al. Hypoxiainduced VEGF and collagen I expressions are associated with angiogenesis and fibrogenesis in experimental cirrhosis. Hepatology. 2002;35:1010-21.

120. Aleffi S, Petrai I, Bertolani C, Parola M, Colombatto S, Novo E, et al. Upregulation of proinflammatory and proangiogenic cytokines by leptin in human hepatic stellate cells. Hepatology. 2005;42:1339-48.

121. Taura K, De Minicis S, Seki E, Hatano E, Iwaisako K, Osterreicher CH, et al. Hepatic stellate cells secrete angiopoietin 1 that induces angiogenesis in liver fibrosis. Gastroenterology. 2008;135:1729-38.

122. Wirz W, Antoine M, Tag CG, Gressner AM, Korff T, Hellerbrand C, et al. Hepatic stellate cells display a functional vascular smooth muscle cell phenotype in a three-dimensional co-culture model with endothelial cells. Differentiation. 2008;76:784-94.

123. Kang N, Gores GJ, Shah VH. Hepatic stellate cells: partners in crime for liver metastases? Hepatology. 2011;54:707-13.

124. Ankoma-Sey V, Wang Y, Dai Z. Hypoxic stimulation of vascular endothelial growth factor expression in activated rat hepatic stellate cells. Hepatology. 2000;31:141-8

125. Borkham-Kamphorst E, van Roeyen CRC, Ostendorf T, Floege J, Gressner AM, Weiskirchen R. Pro-fibrogenic potential of PDGF-D in liver fibrosis. J Hepatol. 2007;46:1064-74

126. Novo E, Cannito S, Zamara E, Valfrè di Bonzo L, Caligiuri A, Cravanzola C, et al. Proangiogenic cytokines as hypoxia-dependent factors stimulating migration of human hepatic stellate cells. Am J Pathol. 2007;170:1942-53.
127. Torimura T, Sata M, Ueno T, Kin M, Tsuji R, Suzaku K, et al. Increased expression of vascular endothelial growth factor is associated with tumor progression in hepatocellular carcinoma. Hum Pathol. 1998;29:986-91.

128. Coulouarn C, Corlu A, Glaise D, Guénon I, Thorgeirsson SS, Clément B. Hepatocyte-stellate cell cross-talk in the liver engenders a permissive inflammatory microenvironment that drives progression in hepatocellular carcinoma. Cancer Res. 2012;72:2533-42.

129. Lin N, Chen Z, Lu Y, Li Y, Hu K, Xu R: Role of activated hepatic stellate cells in proliferation and metastasis of hepatocellular carcinoma. Hepatol Res 2014;34:704.

130. Torimura T, Ueno T, Kin M, Harada R, Taniguchi E, Nakamura T, et al. Overexpression of angiopoietin-1 and angiopoietin-2 in hepatocellular carcinoma. J Hepatol. 2004;40:799-807.

131. Qu H, Yang X. Metformin inhibits angiogenesis induced by interaction of hepatocellular carcinoma with hepatic stellate cells. Cell Biochem Biophys. 2015;71:931-6.

132. Bhat M, Chaiteerakij R, Harmsen WS, Schleck CD, Yang JD, Giama NH, et al. Metformin does not improve survival in patients with hepatocellular carcinoma. World J Gastroenterol. 2014;20:15750-5.

133. Bianchi G, Borgonovo G, Pistoia V, Raffaghello L. Immunosuppressive cells and tumour microenvironment: focus on mesenchymal stem cells and myeloid derived suppressor cells. Histol Histopathol. 2011;26:941-51.

134. Ormandy LA, Hillemann T, Wedemeyer H, Manns MP, Greten TF, Korangy F. Increased populations of regulatory $T$ cells in peripheral blood of patients with hepatocellular carcinoma. Cancer Res. 2005;65:2457-64.

135. Fu J, Xu D, Liu Z, Shi M, Zhao P, Fu B, et al. Increased regulatory T cells correlate with CD8 T-cell impairment and poor survival in hepatocellular carcinoma patients. Gastroenterology. 2007;132:2328-39.

136. Facciabene A, Motz GT, Coukos G. T-regulatory cells: key players in tumor immune escape and angiogenesis. Cancer Res. 2012;72:2162-71.

137. Chen K-J, Zhou L, Xie H-Y, Ahmed T-E, Feng X-W, Zheng S-S. Intratumoral regulatory $T$ cells alone or in combination with cytotoxic $T$ cells predict prognosis of hepatocellular carcinoma after resection. Med Oncol. 2012;29:1817-26.

138. Ostrand-Rosenberg S, Sinha P. Myeloid-derived suppressor cells: linking inflammation and cancer. J Immunol. 2009;182:4499-506.

139. Xia Y, Chen R, Ye S-L, Sun R, Chen J, Zhao Y. Inhibition of T-cell responses by intratumoral hepatic stellate cells contribute to migration and invasion of hepatocellular carcinoma. Clin Exp Metastasis. 2011;28:661-74.

140. Xia Y-H, Wang Z-M, Chen R-X, Ye S-L, Sun R-X, Xue Q, et al. T-cell apoptosis induced by intratumoral activated hepatic stellate cells is associated with lung metastasis in hepatocellular carcinoma. Oncol Rep. 2013;30:1175-84.

141. Zhao W, Zhang L, Xu Y, Zhang Z, Ren G, Tang K, et al. Hepatic stellate cells promote tumor progression by enhancement of immunosuppressive cells in an orthotopic liver tumor mouse model. Lab Invest. 2014;94:182-91.

142. Chen C-H, Kuo L-M, Chang Y, Wu W, Goldbach C, Ross MA, et al. In vivo immune modulatory activity of hepatic stellate cells in mice. Hepatology. 2006;44:1171-81.

143. Yu M-C, Chen C-H, Liang X, Wang L, Gandhi CR, Fung JJ, et al. Inhibition of T-cell responses by hepatic stellate cells via B7-H1-mediated T-cell apoptosis in mice. Hepatology. 2004;40:1312-21.

144. Muhanna N, Horani A, Doron S, Safadi R. Lymphocyte-hepatic stellate cell proximity suggests a direct interaction. Clin Exp Immunol. 2007;148:338-47.

145. Dong H, Strome SE, Matteson EL, Moder KG, Flies DB, Zhu G, et al. Costimulating aberrant $\mathrm{T}$ cell responses by $\mathrm{B} 7-\mathrm{H} 1$ autoantibodies in rheumatoid arthritis. J Clin Invest. 2003;111:363-70.

146. Kuipers H, Muskens F, Willart M, Hijdra D, van Assema FBJ, Coyle AJ, et al. Contribution of the PD-1 ligands/PD-1 signaling pathway to dendritic cell-mediated CD4+ T cell activation. Eur J Immunol. 2006;36:2472-82.

147. Ni L, Ma CJ, Zhang Y, Nandakumar S, Zhang CL, Wu XY, et al. PD-1 modulates regulatory $T$ cells and suppresses $\mathrm{T}$-cell responses in $\mathrm{HCV}$-associated lymphoma. Immunol Cell Biol. 2011:89:535-9.

148. Francisco LM, Salinas VH, Brown KE, Vanguri VK, Freeman GJ, Kuchroo VK, et al. PD-L1 regulates the development, maintenance, and function of induced regulatory T cells. J Exp Med. 2009;206:3015-29.

149. McDermott DF, Atkins MB. PD-1 as a potential target in cancer therapy. Cancer Med. 2013;2:662-73.

150. Brahmer JR, Drake CG, Wollner I, Powderly JD, Picus J, Sharfman WH, et al, Phase I study of single-agent anti-programmed death-1 (MDX-1106) in refractory solid tumors: safety, clinical activity, pharmacodynamics, and immunologic correlates. J Clin Oncol. 2010;28:3167-75. 
151. Sznol M, Powderly JD, Smith DC, Brahmer JR, Drake CG, McDermott DF, Lawrence DP, Wolchok JD, Topalian SL, Lowy I: Safety and antitumor activity of biweekly MDX-1106 (Anti-PD-1, BMS-936558/ONO-4538) in patients with advanced refractory malignancies. 2010 ASCO Annual Meeting Abstracts.

152. Henderson NC, Arnold TD, Katamura Y, Giacomini MM, Rodriguez JD, McCarty JH, et al. Targeting of av integrin identifies a core molecular pathway that regulates fibrosis in several organs. Nat Med. 2013;19:1617-24.

153. Mederacke I, Hsu CC, Troeger JS, Huebener P, Mu X, Dapito DH, et al. Fate tracing reveals hepatic stellate cells as dominant contributors to liver fibrosis independent of its aetiology. Nat Commun. 2013;4:2823.

154. Poelstra K, Beljaars L, Melgert BN. Cell-specific delivery of biologicals: problems, pitfalls and possibilities of antifibrotic compounds in the liver. Drug Discov Today. 2013;18:1237-42.

155. Elrick L, Leel V, Blaylock MG, Duncan L, Drever MR, Strachan G, et al. Generation of a monoclonal human single chain antibody fragment to hepatic stellate cells-a potential mechanism for targeting liver anti-fibrotic therapeutics. J Hepatol. 2005;42:888-96.

156. Sato Y, Murase K, Kato J, Kobune M, Sato T, Kawano Y, et al. Resolution of liver cirrhosis using vitamin A-coupled liposomes to deliver siRNA against a collagen-specific chaperone. Nat Biotechnol. 2008;26:431-42.

157. Klein S, Van Beuge MM, Granzow M, Beljaars L, Schierwagen R, Kilic S, et al. HSC-specific inhibition of Rho-kinase reduces portal pressure in cirrhotic rats without major systemic effects. J Hepatol. 2012;57:1220-7.

158. Moreno M, Gonzalo T, Kok RJ, Sancho-Bru P, van Beuge M, Swart J, et al. Reduction of advanced liver fibrosis by short-term targeted delivery of an angiotensin receptor blocker to hepatic stellate cells in rats. Hepatology. 2010;51:942-52.

159. Beljaars L, Weert B, Geerts A, Meijer DKF, Poelstra K. The preferential homing of a platelet derived growth factor receptor-recognizing macromolecule to fibroblast-like cells in fibrotic tissue. Biochem Pharmacol. 2003;66:1307-17.

160. Schoemaker MH, Rots MG, Beljaars L, Ypma AY, Jansen PLM, Poelstra K, et al. PDGF-receptor beta-targeted adenovirus redirects gene transfer from hepatocytes to activated stellate cells. Mol Pharm. 2008;5:399-406.

161. Beljaars L, Molema G, Schuppan D, Geerts A, De Bleser PJ, Weert B, et al. Successful targeting to rat hepatic stellate cells using albumin modified with cyclic peptides that recognize the collagen type VI receptor. J Biol Chem. 2000;275:12743-51.

162. Du S-L, Pan H, Lu W-Y, Wang J, Wu J, Wang J-Y. Cyclic Arg-Gly-Asp peptide-labeled liposomes for targeting drug therapy of hepatic fibrosis in rats. J Pharmacol Exp Ther. 2007;322:560-8.

163. Bansal R, Prakash J, De Ruiter M, Poelstra K. Targeted recombinant fusion proteins of IFNy and mimetic IFNy with PDGFBR bicyclic peptide inhibits liver fibrogenesis in vivo. PLoS One. 2014;9, e89878.

164. Bansal R, Prakash J, De Ruiter M, Poelstra K. Interferon gamma peptidomimetic targeted to hepatic stellate cells ameliorates acute and chronic liver fibrosis in vivo. J Control Release. 2014;179:18-24.

165. Bansal R, Prakash J, Post E, Beljaars L, Schuppan D, Poelstra K. Novel engineered targeted interferon-gamma blocks hepatic fibrogenesis in mice. Hepatology. 2011;54:586-96.

\section{Submit your next manuscript to BioMed Central and take full advantage of:}

- Convenient online submission

- Thorough peer review

- No space constraints or color figure charges

- Immediate publication on acceptance

- Inclusion in PubMed, CAS, Scopus and Google Scholar

- Research which is freely available for redistribution 